Dr.phil, lektor ved Retorik, Institut for Kommunikation og Kultur, Aarhus Universitet

\title{
RETORIK OG LYKKE
}

\section{Arven fra Aristoteles og græsk eudaimonisme}

Samtidig med opkomsten af de demokratisk styrede græske bystater i det femte århundrede f.v.t. bliver det efterhånden en udbredt forestilling blandt frie mænd, at lykke (eudaimonia) er et menneskeligt mål, der er tæt forbundet med retorik. Dette skyldes formentlig, at evnen til at kommunikere på en så overbevisende og hensigtsmæssig måde som muligt uvilkårligt kommer til at indgå i den almene stræben mod lykke som det samlede mål for menneskelige handlinger. I en lang række praktiske sammenhænge drøftes og forhandles der om, hvad der er det bedste for bystaten, eller hvad der i stridsmål er en retfærdig dom, og eftersom bystaten bl.a. har til formål at sikre den enkeltes lykke, og da retorik netop bliver udviklet med henblik på at kunne føre demokratiske drøftelser og gennemføre civile retshandlinger, får retorik en meget direkte indflydelse på spørgsmålet om, hvordan lykke opnås.

Forbindelsen mellem retorik og lykke forstået som eudaimonia, hvilket også kan oversættes "velbefindende", "menneskelig blomstring" eller, mere direkte, "god ånd", bliver udlagt forskelligt i den græske antik. På trods af at den er ret upåagtet, har denne forbindelse ikke desto mindre afgørende betydning for Aristoteles og bliver ganske grundigt behandlet i hans Retorik i direkte dialog med hans Etik og Statslære. Ud fra dens betydningspoten- 
tialer for den nutidige anvendelse af retorik skal vi i det følgende forsøge en rationel rekonstruktion af en række centrale elementer i denne sammenhæng med vægt på Aristoteles. Som illustrativt eksempel inddrager vi en analyse af Perikles' eulogi, og vi afslutter med et kort perspektiv på, hvordan forbindelsen mellem retorik og lykke ikke blot er central i græsk antik, men også har klare aktualiseringsmuligheder i vores egen samtid.

\section{LYKKE SOM RETORISK GRUNDPRÆMIS}

Aristoteles' udlægning af sammenhængen mellem retorik og lykke er især knyttet til politiske spørgsmål, og han anvender eudaimonia som et lykkebegreb snævert knyttet til veldefinerede forestillinger om dyd, forstandighed, det gode liv og det fælles bedste. Hermed distancerer han sig fra andre af antikkens lykkebegreber, bl.a. hēdonē, jf. hedonisme, den lystfølelse der for ham blot er et ledsagefænomen til en aktivitet, hvor lykken bliver udtømt i og med aktiviteten. Ligeledes må han lægge afstand til i hvert fald den arkaiske forståelse af olbos, dvs. en livslykke forbundet med velstand eller stor formue, hvilket for Aristoteles nok kan være et gode, men ikke er identisk med lykke forstået som det, der har sit formål i sig selv.

I sammenhæng med retorik er det altså forståelsen af lykke som eudaimonia, der er vigtig. Aristoteles bemærker i Etikken, at de fleste, "både mængden og de dannede", er enige om at kalde "det højeste af alle praktiske goder" for lykke, og "at leve godt og handle vel [er] identisk med lykken (eudaimonia)" (Etikken 33, 1095a). Derfor er der også en høj grad af konsekvens i, som han fremstiller det i Retorik, at en retor i en deliberativ situation, hvor der forhandles og rådslås om politiske spørgsmål, men også i debatter om "andre sager", skal "hente de argumenter, han må lægge til grund for sin tilråden og fraråden", netop fra spørgsmålet om "lykken (eudaimonia) og dens bestanddele. [...] For det er om den og det, der fremmer eller modvirker den, enhver tilråden eller fraråden drejer sig" (Retorik 48-49, 136ob). Aristoteles er dog udmærket klar over, at langtfra alle er enige om, hvad lykken er, eller "hvori dens enkelte dele består" (ibid.): "på spørgsmålet om hvad lykken er, hersker der uenighed, og mængden giver ikke samme svar som de vise" (Etikken 33, 1095a). Så selv om han forholdsvis problemløst kan give en formel bestemmelse af lykke som det samlede 
mål for menneskelige handlinger, så forholder han sig til spørgsmålet om lykke i en åbenhed over for den herskende strid om indholdet af lykke. Man kan dog sige, at Aristoteles selv anvender retorik i sine videre etiske bestemmelser af lykke, og at han argumenterer ganske overbevisende for eudaimonia som resultatet af en aktiv bestræbelse på at opøve og udøve såvel praktiske som intellektuelle dyder.

På grund af denne strid om, hvori lykke består, må man samtidig understrege, at såvel etisk deliberation om det gode som retorisk deliberation om det nyttige eller hensigtsmæssige står sig bedst ved eksplicit at definere og argumentere ud fra eudaimonia, der ifølge Aristoteles generelt understøtter deliberativ argumentation. De to former for deliberation bliver til tider fortolket som uafhængige af hinanden, hvorved retorik reduceres til en teknisk kompetence med det nyttige som et mål i sig selv, således at retorisk deliberation bliver en kynisk kalkulation af, hvordan det nyttige lader sig realisere, mens alene etisk deliberation skulle have det gode som sit mål. ${ }^{1}$ Men Aristoteles viser klart, hvordan retorisk deliberation på én gang er rettet mod det nyttige og det gode som sit mål, når der argumenteres med udgangspunkt i lykke: "Dette er det materiale, hvorfra man må hente sine bevismidler med hensyn til det gode (agathon) og det nyttige (sumpherontos)" (Retorik 58, 1363b). ${ }^{2}$

Hvis retorisk overbevisningskraft således henter sin styrke fra spørgsmålet om lykke, fungerer denne som iboende, men ofte uudtalt grundpræmis bag en hvilken som helst argumentation, der taler for eller imod en sag med henblik på at ændre eller fastholde tingenes tilstand eller med henblik på at ændre et publikum eller en samtalepartners handlinger eller holdninger. I denne præcise forstand, hvor en argumentation søger at fremme et synspunkt om, hvad der i given situation er bedst og mest nyttigt eller hensigtsmæssigt, er retorik på et grundlæggende niveau forbundet med

1 Olmsted og Garver er blandt de få, der har åbnet for en anden fortolkning, hvor de to former for deliberation netop sættes i forbindelse med hinanden. Garver understreger, at "den personlige etiske deliberations metoder er de samme som den retoriske deliberation og overtalelsens metoder" (2006, 90).

2 Om sammenhængen mellem det gode og det nyttige, jf. Richard Krauts "Aristotle on Well-Being", hvor han foreslår at læse Aristoteles' anvendelse af det gode (agathon) som en bekræftelse af, hvad der er nyttigt (sumpheron) (23). 
lykke, og man kan derfor hævde, at forståelsen og anvendelsen af retorik udgør en forudsætning for opnåelsen af lykke.

\section{ET EPIDEIKTISK ARGUMENT FOR LYKKE}

En sådan udlægning af Aristoteles' forståelse af forbindelsen mellem retorik og lykke tager hensyn til den etiske og politiske ramme, han selv udstikker for sin systematiske udvikling af den retoriske kunst. Vi skal kort undersøge, hvordan Aristoteles' retorisk-etiske forståelse af lykke kan anvendes som analytisk redskab og vurderingskriterie i udlægningen af taler med eksempel i én af den græske antiks mest berømte taler, Perikles' gravtale eller eulogi. Talen bliver holdt i forbindelse med krigerbegravelsen af faldne atheniensiske soldater i slutningen af det første år af Den Peloponnesiske Krig (431-404 f.v.t.), og helt op til vores tid har den dannet model for eulogier i beslægtede retoriske situationer. Vi har ikke talen overleveret ordret, men den er gengivet i skriftlig form af den græske historiker Thukydid i Den Peloponnesiske Krigs Historie, nok præget af dennes stil, hvad der dog er mindre vigtigt i vores sammenhæng. Og selv om den græske statsmand, general og retor Perikles (495-429 f.v.t.) lever hundrede år før Aristoteles (384-322 f.v.t.) og fortolker statens ledelse med henblik på at begunstige opnåelsen af lykke noget anderledes end Aristoteles, så følger hans retorik den aristoteliske grundstruktur med lykke som styrende præmis ikke kun for egentlige argumenter, men også for selve genrens traditionelle hovedærinde, at ære de faldne og trøste de efterladte.

Umiddelbart har eulogien som epideiktisk genre, dvs. lejlighedstale, altså hverken et politisk-deliberativt mål eller lykke som sit emne. Ifølge Aristoteles har genren det som sin præcist definerede opgave "at udtale ros eller dadel" (Retorik 43, 1358b). Perikles følger ganske vist i nogen grad samtidens hævdvundne skema for en eulogi: en indledning om situationen og dens krav; en lovprisning af forfædrene, fædrelandet og de faldne; en klage over de faldne, her omarbejdet til en appel om at følge de faldnes eksempel; en trøst til de efterladte; og en afslutning. Alligevel fremviser talen klare deliberative træk vedrørende Athens demokratiske styreform, atheniensernes særlige dyder samt staten og borgernes fælles lykke. Helt ned i stilen er talen karakteristisk ved sine logiske argumenter, og den længste passage 
(Thukydid, kap. 37-43) er båret af deliberative argumenter for Athens storhed. Argumenterne er opbygget som gendrivelser af negativt konstruerede positioner for at fremholde det positive ved Athens demokrati og kultur, de atheniensiske dyder og traditioner. De følger altså den antitetiske struktur: "Ikke sådan ..., men sådan ...", fx: "Den statsform vi har er ikke en efterligning af vores naboers love; nej, vor statsform er snarere selv et eksempel for andre ..." (26, kap. 37). Så på trods af genrekravene, som ligefrem er lovfæstede, hvilket Perikles omtaler både i indledningen og i afslutningen (jf. 25, kap. 35 og 31, kap. 46), bliver eulogien med sin altoverskyggende lovprisning af demokratiet et politisk partsindlæg. Perikles har selv været med til at frembringe og forme Athens demokrati og argumenterer her, at statens styreform er forudsætningen for den frihed og lykke, som de faldne har kæmpet for.

Vi kan læse talen i forlængelse af Aristoteles' forståelse af sammenhængen mellem retorik og lykke, der i princippet altid gør det muligt at foretage en etisk vurdering af den anvendte retorik ud fra det, man kunne kalde for "lykketesten". Denne test skal afgøre, om en given retorisk aktivitet anvender en velovervejet og korrekt form for deliberation, dvs. med det gode såvel som det nyttige for øje, men hvor det nyttige er underordnet det gode. Lykketesten sætter således, at målet for enhver retorisk aktivitet er lykke, og at selve den kritiske vurdering af retorik og argumentation bidrager til lykkens fremme, for så vidt den kritiske aktivitet formår at holde sig lykke som retorisk grundpræmis for øje. Testen må først spørge til den karakter (ethos), hvormed en retor fremtræder i og med sin tale, og vurdere talerens etiske eksempel: Hvem taler? Fatter man tillid til talerens karakter, kan man dernæst gå over til den egentlige vurdering af, hvordan og i hvilket omfang de fremførte argumenter og handlingsanvisninger, retorikkens tilråden og fraråden, kan siges at begunstige lykken. Det etiske grundspørgsmål til retorikken i en sådan test bliver da: Hvem tjener retorikken? Eller: Hvis lykke tilgodeses? ${ }^{3}$

3 Jf. også det latinske "Cui bono?", "hvem gavner det?" eller "godt for hvem?", der især er blevet berømt gennem Ciceros forsvarstale Pro Roscio Amerino, og som endnu anvendes som emblematisk udtryk for, at den skyldige i en forbrydelse ofte kan være den, der drager størst fordel af den. 
I Perikles' tilfælde kan man iagttage, hvordan han i indledningen giver tilhørerne mulighed for at tillægge ham en høj grad af ethos, ikke kun ved at belægge sine ord i overensstemmelse med situationen og lovens krav, men også gennem en spidsfindig udlægning af selve talesituationen. Herved fremstår han ydmyg over for situationen, og samtidig viser han sig vidende om dens krav, fremviser dyder tilhørerne kan genkende som deres egne og udviser desuden velvilje over for dem. ${ }^{4}$ Han gør dette ved først at opstille en antitese mellem ord og handling, idet han gør gældende, at ord ikke rækker til at lovprise de faldne: "Jeg ville nu synes det var nok, om man viste sin respekt i gerning for de mænd, der har vist deres mod i gerning, med de offentlige ceremonier som I kan se finde sted også nu ved denne grav" (25, kap. 35). Dernæst underspiller han indirekte sine egne evner som taler: "jeg synes ikke man skulle lade det afhænge af een mands bedre eller ringere talegaver om mange mænds heltemod fik en troværdig omtale" (ibid.). Og endelig søger han at stemme den differentierede tilhørerskares forventningshorisont gunstigt (de faldnes forældre, hustruer og børn, almindelige borgere, nuværende og fremtidige soldater, venner og modstandere, tilrejsende mv.) ved at gøre opmærksom på, at nogle måske nok kan være medvidende og sympatisk indstillede, mens andre vil være uerfarne og misundelige over den hæder, der bliver gjort de faldne til del: "det er svært at holde det rette mål, når man taler om et emne hvor man knapt nok har et fast grundlag for hvad tilhørerne vil mene er sandt" (ibid.). Ved på denne måde at fremføre tre argumenter for, at talen, sådan som den fungerer i overensstemmelse med loven, egentlig er overflødig, vanskelig at holde og flertydig i sit budskab, fremstår Perikles i tilhørernes øjne ydmyg over for situationen, indsigtsfuld, dydig og imødekommende, og han har derved med stor overbevisning begunstiget, at de kan tillægge ham en høj grad af ethos.

Dette er en vigtig forudsætning for at fremsætte det centrale argument i talen: at det atheniensiske demokrati er værd at kæmpe og dø for, fordi

4 Dette svarer til Aristoteles' tre ethos-dyder, "der gør, at en taler virker overbevisende": klogskab (phronēsis), moralsk karakter (aretē) og velvilje (eunoia) (jf. Retorik 113, 1378a). Disse dyder bliver her struktureret gennem anvendelsen af den retoriske figur excusatio propter infirmitatem, dvs. en ydmyghedstopos, der er underordnet indledningens captatio benevolentiae, dens stræben mod velvilje. 
det sikrer borgerne deres lykke. Uden at gå i detaljer er det muligt at iagttage talen som organiseret omkring en dobbelt-struktur af dyder, byens og borgerens, således at byen gennem sin styreform giver den enkelte borger frihed og lykke, og borgeren gennem sine handlinger sikrer demokratiets institutioner. Ud over sansen for frihed, som i den henseende er den strukturerende dyd, omtaler Perikles en række andre dyder, som han fremstiller som karakteristiske for atheniensere, især mandsmod er her væsentlig, men også retfærdighed, sansen for skønhed, sansen for visdom og storsind fremhæves. Det centrale afsnit om Athens storhed kulminerer i en lovprisning af de faldnes indsats: "den er deres by værdig" (29, kap. 43), efterfulgt af den vigtigste appel: "De skal være jeres idealer nu: Sæt lykke (eudaimon) lig frihed, frihed lig mod, og sky ikke krigens fare" (29-30, kap. 43).

I den efterfølgende trøst er det igen den demokratisk sikrede lykke, der betones, hvorfor den heller ikke udformes som "en klage, men snarere en opmuntring" (30, kap. 44). To afsnit henvendt til de faldnes forældre lyder her:

I véd jo at jeres liv er faldet i en tid fuld af urolige begivenheder; og den har haft en lykkelig lod, der som de nu får den smukkeste død, eller som I, den smukkeste sorg, og hvem et liv i lykke og en tilsvarende død er blevet tilmålt. Jeg véd godt at det er svært at få jer til at tro: Tit og ofte vil I blive mindet om jeres børn, når I ser andres lykke, som I også selv engang frydede jer ved; og man sørger ikke over de glæder der tages fra én uden at man har prøvet dem, men over det man mister efter at have været fortrolig med det. [...] Og I der ikke er unge længere, regn I jer som gevinst at I har været lykkelige i det meste af jeres liv, og at jeres liv nu vil blive kort, og lad disse mænds ry lette jeres byrde. Thi æren er det eneste der ikke ældes, og i den alder hvor man ikke kan gøre nytte har man ikke, som nogle påstår, mest glæde af at tage gevinster hjem, men af at nyde ære (30, kap. 44).

Selv om Perikles i disse to afsnits drøftelse af lykke kun en enkelt gang anvender en sproglig variant af eudaimonia (ved "et liv i lykke"), er det tydeligvis lykke som topos, der fungerer som grundpræmis for argumenterne. Det overordnede udsagn er altså, at det liv, der er forløbet i lykke, også ender i lykke, således at der også i døden er lykke. Derfor er der heller ingen grund til at beklage de døde, tværtimod er døden ret beset en lykke, og Perikles kan følgelig afslutte talen med ordene: "Bring nu klagen til ende, hver over jeres egne, og gå så bort" (31, kap. 46). 
Vurderet på baggrund af vores lykketest må talen i kraft af sine overbevisende argumenter for et livs lykke beseglet med en lykkelig død siges at være usædvanlig vellykket. Perikles' ethos styrkes af hans retoriske evne til ud fra lykke som grundpræmis at omarbejde eulogiens genrekrav på en sådan måde, at tilhørerne får anskueliggjort, hvorfor de faldnes offer under de givne omstændigheder ikke blot er nyttigt eller nødvendigt, men også godt, ja, faktisk tjener det højeste gode, lykken. De fremstillede, men vel nok fingerede vanskeligheder i talesituationen, hvormed Perikles stemmer tilhørernes forventninger, og antitesen mellem ord og handlinger overvindes af retorik, idet deliberationen for den gensidige afhængighed mellem statslige og individuelle hensyn understøtter den epideiktiske hædring af de faldne. Retorikken er derfor også mere end et redskab, der tjener situationen; den bliver i situationen selve lykkens genuine udtryk, idet den gennem sin struktur og i sine mange fyndige formuleringer fejrer sin egen evne til at fremvise, hvad der såvel i den konkrete situation som i bystaten i almindelighed er lykke.

\section{RETORISK FAGLIGHED OG DELIBERATIONEN OM LYKKE}

Aristoteles' forståelse af retorikkens forbindelse med lykke er udviklet i en græsk sammenhæng, hvor der findes forskellige udlægninger af retorik som et etisk og åndeligt anliggende, der ikke kun har overtalelse som sit mål, men også angår såvel den enkelte som samfundets lykke. Ganske vist har en pragmatisk anvendelse af retorik som politisk magtinstrument nok været den mest udbredte, ikke mindst i Athen, hvor de vigtigste politiske spørgsmål og statens ledelse bliver afgjort gennem borgernes offentlige diskussioner, hvorfor retorik selvsagt har været en højt skattet færdighed, ihærdigt studeret og flittigt opøvet. Ifølge den franske historiker og antropolog Jean-Pierre Vernant bliver talen slet og ret det væsentligste magtinstrument i de demokratiske bystater: "Polis-systemet medførte først og fremmest, at talen fik en usædvanlig forrang frem for andre magtinstrumenter. Den blev det politiske redskab par excellence, nøglen til enhver form for autoritet i Staten, midlet til at herske over og dominere andre" (40). Især inden for politik har deliberationen om det nyttige imidlertid gerne underforstået, at det mest nyttige er det, der bedst fremmer bystatens lykke. 
I samme periode indføres et nyt retssystem i Athen, hvor domsafgørelser træffes af en jury udvalgt gennem lodtrækning blandt borgerne, og hvor de involverede parter i retssagen selv skal føre deres sag uden bistand fra advokater. Også i den situation kan en mands lykke naturligvis stå og falde med evnen til at beherske talekunsten, eller med midlerne til at betale en dygtig taleskriver, der formår at forfatte en overbevisende tale.

Fremkomsten af retorik som en kunst i sin egen ret, en færdighed i at tale og argumentere overbevisende, hænger således uløseligt sammen med udviklingen af demokratiske samfundsinstitutioner, men den retoriske kompetence inddrages også i de udbredte diskussioner af etiske spørgsmål, og for flere lærde i den græske antik bliver det snart klart, at retorik fremmer andet og mere end rent magtpolitiske mål. Grækerne, især athenienserne, ligesom senere romerne, er simpelthen begejstrede for talekunst: "Man betragtede [...] ikke blot talen som det nødvendige grundlag for samfundslivet. Talekunsten var kronen på selve det at være menneske. Derfor blev der efterhånden flere og flere, der ønskede at gøre den til hovedsagen i ungdommens opdragelse" (Fafner 26). Netop fordi evnen til at tale godt af mange efterhånden også bliver betragtet som et middel til virkeliggørelsen af det højeste, etiske mål for menneskelig stræben, nemlig lykke, begynder retorik også at blive opfattet som et mål i sig selv og dermed som en kunst.

Udviklingen af retorikken i det fjerde århundrede f.v.t. fører til, at den praktiske anvendelighed af talekunst til sidst, dvs. hos Aristoteles, bliver gjort til genstand for en filosofisk refleksion og, med græsk terminologi, lader sig bestemme som en egentlig technē, en færdighed og kunst i sin egen ret, et fag med specifikke opgaver. Dels er det ifølge Aristoteles retorikkens opgave (ergon) "at pege på de overbevisende momenter, der foreligger" eller "at mønstre de mulige overbevisende momenter i ethvert givet stof" (Retorik 33, 1355b), dels at beskæftige sig med de ting, "vi drøfter og rådslår om" (37, 1357a). Det er bl.a. under henvisning til den sidste definition, at Wendy Olmsted har kunnet vise, hvorfor deliberation, og dermed spørgsmålet om lykke, i realiteten er relevant i alle former for retorik:

Retorik rummer belæg for at identificere deliberation med retorik i mere bred forstand. Fordi den argumenterer, at retorik henter sit materiale ud fra almindelige deliberative emner (12.1356b33), og definerer retorikkens funktion som værende om de ting, vi drøfter og rådslår om (bouleuōmetha [delibererer]), og hvortil vi ikke 
har specielle fag (tēchnas, 1.2.1357a1-2), bliver deliberation et definerende træk ved retorik" (257).

Det betyder endvidere, at den retoriske deliberations nytte bliver ærværdig og god i etisk forstand, fordi den tjener det fælles bedste og dermed begunstiger lykken. Som vi så hos Perikles, er det med udgangspunkt i en sådan etisk forpligtet nytte, at han anvender sin retorik til at lovprise de idealer, for hvilke man selv i krig bør friste sin lykke: "Sæt lykke lig frihed, frihed lig mod, og sky ikke krigens farer".

Aristoteles fremhæver desuden, at retorikkens "opgave ikke i og for sig er at overbevise nogen" (Retorik 33, 1355b), og han sammenligner i den henseende retorik med lægekunsten, der ikke har det som sit egentlige mål "at gøre folk raske, men at hjælpe dem så langt frem i den retning, som det er muligt" (ibid.). Det særlige ved talekunst og lægekunst er nemlig, at de begge har både et ydre og et indre mål, og det, der overhovedet gør dem til technai, er, at det indre mål er dominerende. Hvis retorik blot havde det ydre mål at overbevise, ville det stemme bedre overens med en udbredt moderne opfattelse af retorik som en ren teknisk kompetence, men retorik har altså også et indre, retledende eller konstitutivt mål, der desuden sætter kunstneriske og etiske normer for, hvad der gør den gode retorik god. ${ }^{5}$ Det er bl.a. derfor, at god retorik ikke nødvendigvis lykkes med hensyn til at overbevise andre om det hensigtsmæssige eller fordelagtige i de fremstillede anbefalinger. Men væsentligere er det, at retorik i den henseende deler et nært slægtskab med enhver dyd, hvor lykke opnås ved at efterleve dydens indre mål for dens egen skyld, på samme måde som

5 I Aristotle's Rhetoric analyserer Garver grundigt forskellen mellem technai's indre og ydre mål, jf. især kap. 1. Han bemærker: "For at en kunst kan være mulig, skal der nødvendigvis være, hvad der med vekslende udtryk kan kaldes for et indre gode, et indre mål, et retledende mål eller et konstitutivt mål for den pågældende praksis lige såvel som et ydre, givet mål" (24). Hvis det er retorikkens ydre mål at overbevise, er det dens indre mål, at man så godt som muligt følger dens regler med henblik på at opnå det ydre mål. Det at lykkes i sit forehavende er det ydre mål, hvilket ikke er nok til, at gøre det til en kunst, mens det at gøre sit bedste for at opnå det ydre mål er det indre mål, der gør det til en kunst, også selv om man mislykkes. 
god retorik opnås ved at forfølge dens indre mål. En retorisk dyd vil således være at udmærke sig, at udvise dygtighed og duelighed i bestræbelsen på at realisere dens indre mål.

Der er næppe noget overraskende i, at Aristoteles' forståelse af menneskets praktiske opgaver, dets handlinger og valg, som ifølge Etikken alle "synes at rette sig mod noget godt" $(31,1094 a)$, også omfatter talen. I overensstemmelse med hans teleologiske opfattelse, at alting stræber mod at aktualisere sin potentialitet, er retorikkens opgaver derfor heller ikke adskilt fra andre opgaver. På samme måde som fx militærkunst og økonomi er retorik underordnet den politiske kunst eller statslæren med det præcise sigte på talekunstens vilkår at fremme det gode $(32,1094 \mathrm{~b})$, hvilket i sidste ende vil sige lykke.

Den nærmere sammenhæng mellem retorik og etik bestemmer han i Retorik: "Retorikken bliver med andre ord en slags sidegren af dialektikken og af etikken [...], som rettelig må betegnes som hørende under statslæren (politike)" (35, 1356a). Mennesket er, med et ofte citeret udtryk fra Statslære, slet og ret et "politisk dyr" (zoon politikon), et samfundsvæsen hvis natur det er at indgå i fællesskaber med andre mennesker (77, 1253a). Derfor udgør retorik ifølge statslæren et uundværligt bidrag til samfundet og dets overordnede stræben mod lykke: "Talen tjener til at forklare, hvad der er gavnligt og skadeligt og følgelig ogsaa, hvad der er retfærdigt og uretfærdigt" (78). Eller sagt på en anden måde så bliver den retoriske tale normgivende for, hvad der er dydigt og dermed lykkeligt.

Lykken selv er for Aristoteles en direkte funktion af det at være menneske, hvilket han gør rede for i det såkaldte funktions- eller ergon-argument i syvende kapitel af Etikkens første bog. Efter at have fastslået at lykken er "et fuldkomment og finalt mål [...], som vælges for sin egen skyld og aldrig på grund af noget andet" (39, 1097a), argumenterer han, at for nærmere at forstå den fuldkomne og selvberoende lykke, må vi først gøre rede for, "hvad menneskets funktion er" $(39,1097 \mathrm{~b})$, idet menneskets funktion også er dets mål. Han gør herefter gældende, at ud over forskellige arbejdsmæssige og fysiologiske funktioner har vi mennesker en overordnet funktion, der adskiller os fra alt andet levende og andre væsner, nemlig den funktion, vi som rationelle væsner gør brug af i vores praktiske liv: "sjælens aktivitet og handlinger i overensstemmelse med fornuften 
(logos)" (40, 1098a). Lykke som menneskeligt mål bliver således afhængig af, om vi udøver sjælens aktiviteter og handlinger "godt og smukt", og om vi udøver enhver ting "i overensstemmelse med sin dertilhørende dyd": "[det menneskelige gode bliver da] en sjælens aktivitet i overensstemmelse med dyden" (ibid.).

Lykke er derfor også afhængig af, om vi udøver en retorisk aktivitet i overensstemmelse med dens særlige dyd, hvilket vil sige så godt som muligt at udfinde de overbevisende momenter i et givet stof og at deliberere netop med udgangspunkt i spørgsmålet om "lykken og dens bestanddele" (jf. supra). På den ene side adskiller retorik sig altså ikke fra andre af menneskets forskellige erga, der udøvet med henblik på deres tilhørende dyder alle er underordnet det etiske mål at stræbe mod lykke, men på den anden side er det netop den retoriske aktivitet, der under henvisning til lykke som grundpræmis for en given argumentation sætter os i stand til at forhandle og rådslå om, hvordan vi bedst sikrer bystaten og derigennem den enkeltes velfærd og velbefindende. Det betyder som nævnt, at når man argumenterer inden for rammerne af retorisk deliberation om det nyttige eller hensigtsmæssige, er det for Aristoteles samtidig en etisk deliberation om lykke. Retorikkens opgave er hermed ikke isoleret fra andre opgaver og begrænset til at forfølge retorikkens indre mål, at drøfte og rådslå ud fra en forståelse af de overbevisende momenter i et givet stof, men ud fra det overordnede perspektiv på menneskets funktion er retorik også etisk og politisk forpligtet på at finde netop de argumenter, der retter sig mod det fælles bedste. Et godt argument søger ikke bare at overbevise sit publikum, men retter sig hele tiden mod det højeste gode, fællesskabet og derigennem den enkeltes lykke.

I Retorik giver Aristoteles en indholdsdefinition af lykke, som naturligt nok er præget af hans samtid, men han er, som sagt, også klar over, at der altid vil herske strid om, hvad vi forstår ved lykke. Han sætter "lykken lig med velvære i forbindelse med moralsk fuldkommenhed, eller med uafhængighed i livsførelse, eller det behageligst mulige liv i garanteret sikkerhed, eller rigdom på gods og slaver i forbindelse med evnen til at bevare og nyttiggøre dem. Så godt som alle er jo enige om, at lykken består i én eller flere af disse ting" (49, 136ob). Han gør dog også samtidig gældende, at man i retorisk sammenhæng vil kunne argumentere ikke blot for, at en given 
handlingsanvisning fører til lykke defineret på en af disse måder, men også til de forskellige goder, der udgør lykkens bestanddele, herunder sindet og kroppens goder, ydre goder som rigdom og berømmelse, men også til en god alderdom, mange og gode venner mv. (jf. 49-58).

\section{FRA GRÆSK EUDAIMONISME TIL MODERNE DYDSETIK}

Udformningen af en sådan opfattelse af retorik som en kunst i sin egen ret rettet mod lykke er uden tvivl en filosofisk bedrift, ikke mindst når man tager i betragtning, at det er præcis forståelsen af retorik som en technē, som Platon har bestræbt sig på at modarbejde, fordi han omvendt mener, at den spærrer for vejen til lykke. Han søger i stedet at instituere en filosofisk-dialektisk tilgang til viden som den eneste farbare vej mod det højeste gode. Derfor bestrider han også direkte, at retorik kan være en technē. I en af sine dialoger lader Platon Sokrates udspørge Gorgias, én af de mest indflydelsesrige sofister der underviser i talekunst, hvad det største gode er, og denne svarer: "det er noget, som virkelig er det største gode, og noget som på en gang giver frihed til menneskene selv, og som samtidig lader den enkelte herske over andre i samme by", og han uddyber, at han hermed mener "evnen til med ord at overbevise ikke kun dommerne i retten, men også rådsmedlemmerne og deltagerne i folkeforsamlingen" (402, 452d). Retorik tilvejebringer og opretholder altså politisk frihed og dermed lykke, sådan som vi også så det hos Perikles.

Gorgias fremstiller hermed sin forståelse af retorik inden for de begrebslige rammer af den udbredte forestilling i perioden, som Ryan K. Balot betegner som "Athens eudaimonistiske ideologi". ${ }^{6}$ Eudaimonisme er den etiske forestilling om, at lykke er afhængig af en livsførelse i overensstemmelse med kulturelt bærende dyder som klogskab, retfærdighed, mod og mådehold, dvs. de fire kardinaldyder, der kan føres tilbage til Platon. Dog mener Platon selv, at retorik er ren overtalelse, der lader samtalepartneren eller publikum blive eksternt motiveret af kræfter uden for sig selv, og der-

6 (296ff). Balot analyserer centrale klassiske tekster, med stor vægt på Perikles' eulogi, med henblik på at vise, hvordan en eudaimonistisk ideologi udvikler sig i snæver sammenhæng med et demokratisk mod til at gøre egne holdninger gældende. 
med i realiteten vildledt, mens filosofisk dialektik derimod er instruktiv og søger at gøre samtalepartneren internt motiveret og dermed retledt af indre kræfter eller tilskyndelser til at finde sandheden i og med sig selv.

Ikke desto mindre er Gorgias' synspunkt ganske udbredt, og det bliver klart fremstillet hos en anden indflydelsesrig figur, Isokrates, der ser undervisning i retorik som en afgørende del af den dannelse, paideia, der sikrer borgerne politisk lykke. Werner Jaeger opsummerer pointeret:

Målet for Isokrates' retoriske dannelse er frembringelsen af den tilstand af fuld-
kommenhed i det menneskelige liv, som han ligesom filosofferne kalder eudai-
monia, altså et objektivt højeste gode, og ikke opnåelsen af indflydelse for egen
vindings skyld. Hypostaseringen af denne dannelsesidé i det guddommeliggjorte
begreb om Logos er et velvalgt middel til at tydeliggøre denne målsætning. For
logos betyder tale forstået som fornuftig tale og gensidig forståelse, der altid beror
på nogle i sidste instans fælles værdiansættelser. Isokrates giver netop denne side
af logos et klart udtryk og gør den herved til den egentlige bærer af det sociale liv
(1028-29 [III/152-53]).

Dette retoriske ideal har haft stor indflydelse på antikkens forståelse af lykke, men også siden har det gjort sig stærkt gældende hos forskellige politiske, religiøse og humanistiske tænkere som Augustin, Dante, Machiavelli, Erasmus, Melanchton, Locke, Vico og Nietzsche. Dets videreførelse op igennem historien skyldes dog nok især romersk retorik, først og fremmest Cicero, der bygger videre på både Isokrates og Aristoteles. Ligesom grækerne er Cicero optaget af retorikkens betydning for statsforvaltningen og som alment samfundsinstituerende redskab, og selv om han også betoner retorikkens æstetiske og erkendelsesteoretiske sider, så fungerer politisk lykke også for ham som organiserende princip for retorikken. Dette er ganske vist også et anliggende, der optager Platon, men til forskel fra Platon, for hvem det politiske mål er samfundsregulering ud fra en filosofisk indsigt i det Gode som sådant, dvs. som en idé der transcenderer retfærdighed og andre dyder, er Cicero, under inspiration især fra Isokrates, kritisk over for en filosofisk idealforestilling om lykke og mener, at det i en mere pragmatiske forstand er selve den politiske og dermed retoriske aktivitet, der fremmer lykken.

Hos Aristoteles og i græsk eudaimonisme i det hele taget kan vi således iagttage et stærkt bånd mellem retorik og lykke: Retorikken bliver 
god gennem sin etiske forpligtelse, men etisk begrundede handlinger rettet mod lykke bliver også først nyttige i sammenhæng med en retorisk dannelse. Derfor kan det undre, at der inden for nutidens interesse for den aristotelisk inspirerede dydsetik og eudaimonisme, der er vokset støt siden udgivelsen i 1981 af Alasdair MacIntyres After Virtue, ikke har været en større bevågenhed over for denne sammenhæng. MacIntyre selv er klar over, at moderne dydsetik med fordel kan videreføre Aristoteles' antagelse om, at "konklusionen på en praktisk syllogisme må være en særlig form for handling" (161). Men i sin gennemgang af Aristoteles' redegørelse for dyderne inddrager han på intet tidspunkt Aristoteles' grundige overvejelser i Retorik over den "praktiske syllogisme", hvor dette praktiske ræsonnement behandles under betegnelsen "enthymeme", også kaldet en "retorisk syllogisme". MacIntyres pointe om, at udsagn og handlinger må være overensstemmende hos det dydige menneske, ville netop kunne belægges mere overbevisende under henvisning til den integritet, der i henhold til Aristoteles' grundantagelser hersker mellem retorik og etik.

På samme måde kan man omvendt problematisere den måde, hvorpå nutidig retorisk kritik og argumentationsteori endnu synes at hænge fast i traditionelle etiske forestillinger udviklet inden for utilitarisme og deontologi. Herved har moderne retorisk kritik både undladt at agte på den oprindelige dydsetiske sammenhæng mellem retorik og eudaimonisme, som vi her har forsøgt at optegne konturerne af, og i vid udstrækning undladt at inddrage moderne dydsetik som vurderingsgrundlag for bedømmelsen af retorik. Når der i dag fremsættes etiske krav til retorik, beror de derfor ofte på abstrakte, universelle regler frem for de specifikke etiske fordringer, som en given retorisk situation sætter til en taler og til talen om det drøftede emne.

Netop spørgsmålet om lykke giver derfor anledning til en fornyet interesse for det dydsetiske perspektiv, som gør sig gældende inden for antikkens forståelse af retorik. Lykke er mindst lige så omstridt et mål i dag som i antikken, hvilket sætter særlige krav til den retorik, der påtager sig den etiske opgave at fremme lykken under henvisning til et givet publikum og ud fra en konkret situation. Så selv om det endnu står tilbage at udvikle en mere omfattende, moderne forståelse af sammenhængen mellem retorik og etik, kan man begynde ved i praksis at fokusere på, i hvilket omfang 
en given retorik forpligter sig på spørgsmålet om lykke, og i hvilket omfang taleren selv sætter et etisk eksempel til efterfølgelse.

Carsten Madsen (f. 1960), dr.phil., lektor ved Retorik, Institut for Kommunikation og Kultur, Aarhus Universitet, uddannet mag.art. og ph.d. i litteraturhistorie. Værker: Arkitektonik - filosofi, arkitektur (s.m. Oxvig, Henrik), København: Det kongelige danske Kunstakademi 1990, Om læsning. Kierkegaard, Jacobsen, Mallarmé og Kafka (ph.d.-afhandling) Aarhus: Aarhus Universitetsforlag 1995, Poesi, tanke \& natur. Per Højholts filosofi og digtning (disputats), Aarhus: Klim 2004. Seneste artikler: "Dronningens nytårstaler skaber et symbolsk udtryk for nationen", i RetorikMagasinet, nr. 95, 2015, "Forhalingens retorik i Kafkas prosakunst", i RetorikMagasinet, nr. 98, 2015.

\section{RHETORIC AND HAPPINESS}

The Legacy from Aristotle and Greek Eudaimonism

This article maps out the function of and interrelationship between the rhetorical and the ethical uses of happiness (eudaimonia) in Aristotle's Rhetoric and Nicomachean Ethics and within the framework of the democratic polis in Greek antiquity. Deliberations about happiness are claimed to interdependently organize Greek rhetoric and structure the moral character (ethos) of people. Through an analysis of Pericles' eulogy it is demonstrated how epideictic oratory can function as an argumentative deliberation that simultaneously advances happiness as a political and a personal goal. It is further proposed that the interrelationship between rhetoric and ethics makes it possible to critically test any rhetorical statement in terms of happiness. Finally, with reference to Alisdair MacIntyre, it is briefly suggested that central arguments of contemporary virtue ethics could be strengthened by taking rhetorical deliberation about happiness into account, just as rhetorical theories about ethos could benefit from the insights of contemporary eudaimonism.

\section{KEYWORDS}

EN: rhetoric, virtue ethics, happiness, eudaimonia, ethos, argumentation, epideictic, deliberation, Aristotle, Pericles 
DK: retorik, dydsetik, lykke, eudaimonia, ethos, argumentation, epideiktik, deliberation, Aristoteles, Perikles

NO: retorikk, dydsetikk, lykke, eudaimonia, ethos, argumentasjon, epideiktik, deliberasjon, Aristoteles, Perikles

SE: retorik, dygdetik, lycka, eudaimonia, ethos, argumentation, epideiktik, deliberation, Aristoteles, Perikles

\section{LITTERATUR}

Aristoteles. Etikken (5. udg.). Frederiksberg: Det lille Forlag, 2009.

Aristoteles. Retorik. København: Museum Tusculanums Forlag, 1983.

Aristoteles. Statslære. København: Gyldendal, 1999.

Balot, Ryan K. Courage in the Democratic Polis: Ideology and Critique in Classical Athens. New York: Oxford University Press, 2014.

Fafner, Jørgen. Tanke og tale. Den retoriske tradition $i$ Vesteuropa. København: C.A. Reitzels Forlag, 1982.

Garver, Eugene. Confronting Aristotle's Ethics: Ancient and Modern Morality. Chicago og London: University of Chicago Press, 2006.

Garver, Eugene. Aristotle's Rhetoric. An Art of Character. Chicago og London: University of Chicago Press, 1994.

Jaeger, Werner. Paideia: die Formung des griechischen Menschen (1934-47), Berlin: Walter de Gruyter, 1989.

Kraut, Richard. "Aristotle on Well-Being". The Routledge Handbook of Philosophy of WellBeing. Red. Guy Fletcher. London og New York: Routledge, 2015. 20-28.

MacIntyre, Alasdair. After Virtue: A Study in Moral Theory (3. udg.). Notre Dame, Indiana: University of Notre Dame Press, 2007.

Olmsted, Wendy. "Ethical Deliberation in Aristotle's Rhetoric and Nicomachean Ethics". Polis: The Journal for Ancient Greek Political Thought, vol. 30, issue 2, University of Cyprus, 2013. 251-273.

Platon. Gorgias. Samlede værker, bd. III. København: Nordisk Forlag, 2011.

Thukydid. Thukydid. Verdens klassikere. København: Gyldendal, 1963.

Vernant, Jean-Pierre. Les origines de la pensée grecque. Paris: PUF, 1962. 
62 KULTUR \& KLASSE * $121 * 2016$ LYKKE 